survey of the demographic and social impact of Malagasy slaves on places as distant as New York and Barbados by drawing on data from the Trans-Atlantic Slave Trade Database. Given the dearth of work on the contribution of Malagasy culture to the English Atlantic colonies, scholars of African culture in the Americas will find this last chapter particularly helpful.

Pirates, Merchants, Settlers, and Slaves is a fascinating work of history that uncovers how diverse pursuits - be they for wealth, freedom, or land - served to interlock distant and relatively small maritime communities across the globe at the end of the seventeenth century. It is a wonderful addition to the growing catalog of works on Atlantic piracy and culture and offers a sophisticated analysis without overbearing technical language. As any good book should do, McDonald's study will leave the reader wanting to know more, and in turn, provoke new and important questions to pursue for budding scholars of early-modern Atlantic, East African, and Indian Ocean history.

\title{
James Dator
}

Goucher College IO2 I Dulaney Valley Road, Baltimore, MD 2 I 204, USA E-mail: James.Dator@goucher.edu doi: $10.1017 /$ S0020859016000286

Sinjen, Beke. Prosa der Verhältnisse. Die Entdeckung der Erzählliteratur durch die Arbeiterbewegung (I863-1906). Klartext Verlag, Essen 2015. 379 pp. $€ 34.95$.

This study explores the development of Arbeiterliteratur, working-class literature, in the crucial years of the German working-class movement. Sinjen's analysis spans the period from the founding of the Allgemeine Deutsche Arbeiterverein (ADAV; General German Workers Association) in $\mathrm{I} 863$ to its consolidation as a mass movement in the last decade of the century and the Massenstreik-Debatte, the debate about the strategic outlook of the Social Democratic Party, which preceded and predetermined the schism between social democrats and communists during World War I. In this politico-historical context, the study finds a trajectory of working-class literature that leads from literature about workers via literature for workers to literature by workers. This development is explicated in a typology of different genres: from "great-novel"-style works via short narratives and novellas to autobiographical writing. Sinjen's study focuses solely on prose writing of different forms and narrative modes, in contrast to mainstream research in the field, which concentrates on poetry and drama.

As Sinjen emphasizes, most of the research so far on Arbeiterliteratur - and most of this research is more than thirty years old - has focused on socio-political developments in society and the working-class movement, so literature was primarily seen as a reflection of external factors; the literary status of the texts - their literaricity, as it were - was widely neglected. This was, if reflected at all, justified by the inferior artistic quality of most of the texts considered here. Arbeiterliteratur was widely seen solely as Tendenzliteratur, tendentious literature. Sinjen's study, however, focuses on the literary characteristics of the texts, which are read with the same care as "high" literature; in doing so, Sinjen tries to "rescue" some of the texts from the condemnation by a strongly, but silently biased literary 
criticism, and, at the same time, the criteria used to differentiate between "high" and "low" are drawn into question. The study aims further to establish a literary category for Arbeiterliteratur in its own right: "social realism". This category is designed to reflect the interdependency of workers' prose fiction with the literature from the well-regarded "bourgeois" or "poetic realism" of the time, while at the same time claiming to establish an autonomous literary value system.

The first, introductory chapter explicates the socio-historical frame of its subject, defining the term Arbeiterliteratur - mainly by rejecting all too narrow and all too reductive definitions - and it circumscribes the desideratum it aims to fulfil. Chapter 2 introduces Georg Weerth's prose narratives as the Vorgeschichte, the Vormärz pre-history of the history that is told in the study's main part, which occupies the next three chapters. The third chapter is dedicated to the three-volume novel Lucinde oder Capital und Arbeit by Johann Baptist von Schweitzer. Sinjen considers the fact that it appeared in I863-1864, just as the ADAV was being founded, to be more than coincidental. Schweitzer, a patrician's son from Frankfurt am Main, was a founding member of the ADAV and became its elected chairman in I 867. Schweitzer's novel is dedicated to the ADAV's founding father, Ferdinand Lassalle, who in a letter called Schweitzer's novel "a means of propaganda of greatest importance". Sinjen convincingly demonstrates that the antagonism between revolutionary and reformatory forces within the workers' movement - an antagonism that was to be overcome in the unification between the ADAV and the more Marxistorientated Sozialdemokratische Arbeiterpartei (SDAP) in I 875, but that would nevertheless wreck the movement's unity in the years before World War I - is already present in Schweitzer's novel, which supports a reformist, evolutionist model of progress. The fourth chapter focuses on three short narratives, published in the feuilleton and almanacs associated with the workers' movement. The longest part of this chapter is dedicated to "Der Faden der Ariadne. Erzählung aus der Zeit des deutsch-französischen Krieges”, which was serialized in the SDAP's Der Volksstaat newspaper between October 1874 and August I875. The fifth chapter focuses on early workers' autobiographies from I 867 to 1906. Special consideration is given here to J.M. Hirsch's “Arbeiter-Biographie”, which was published I867 in the ADAV's Der Social-Democrat (founded by Schweitzer in I865). Sinjen calls Hirsch's text a true "fund", a "trove", and distinguishes it as the "first record of autobiographical writing in the workers' movement". Sinjen concludes her study with a summary.

The overall result is a good read, carefully, yet fluently written and scrupulously investigated. As the author admits en passant in her literature survey, her study is to a large extent fuelled by "curiosity". This attitude is clearly communicated to the reader, who is brought into contact with a whole body of literature that has hitherto been completely ignored by literary historians; a history that, one has to reiterate, is still being written by (or at least from the perspective of) its "winners". Sinjen not only reintroduces the historically and aesthetically discarded Arbeiterliteratur, she also relates it to the canonical literature of the period. Sinjen's efforts to restore a more complete and complex picture of literature in the second half of the nineteenth century are generally successful. Her claim to examine the narrative characteristics of the texts in question is most convincingly achieved in her extensive reading of Lucinde. Sinjen shows that some of the features of the novel, which led to it being condemned as "trivial" or artistically inferior, can be appreciated if the reader is willing to perceive the novel as one that is still in the process of becoming what it is or what it aims to be. At that point, no genuine value system of workers' literature had yet been established, and Lucinde clings parasitically, as it were, to the values of 
"bourgeois realism", as they had been fashioned in the I 850 in the great poetico-political debates between Julian Schmidt and Karl Gutzkow.

In her attempt to rescue Schweitzer's monumental - and clearly even monstrous - novel from the "enormous condescension of posterity", as E.P. Thompson might have put it, Sinjen, however, is also somehow led astray. To demonstrate the innovative and daring achievements and potentials of the novel, Sinjen employs a set of categories that were developed in twentieth-century literary theory to define genuine modern characteristics of literary texts. In other words, it could be said that Sinjen applies a set of genuine modernist categories, such as polyphony, montage, collage, polyperspectivity, autoreferentiality, and complexity, to Schweitzer's novel. Parts of Sinjen's analysis of Lucinde seem to refer to an avant-garde-style artefact of the early twentieth century, which clearly does not adequately respond to the impression an unprejudiced reader gets from the novel.

Instead of reading the novel as a precursor of latter-day modernism, it would be more appropriate to read it as a late appendix to the formal and political experiments of Vormärz literature. Many of the "progressive" features of Schweitzer's novel can already be found, for example, in Louise Otto-Peters's Schloss und Fabrik (I 846); especially the montagestyle combination of fictional and factual narratives, the embedment of political pamphlets, and the recitation of theoretical texts can be found here too. Sinjen seems to notice the blurring in her historical construction when she concedes that the "advanced" literary features that, according to her interpretation, can already be discovered in Lucinde must simultaneously be perceived as a symptom of the fact that working-class literature was "still" (noch) searching for a literary style of its own. Perhaps - and this would be a general counter-thesis to Sinjen's, a counter-thesis, however, that could draw on many of the excellent findings of Sinjen's study working-class literature in the second half of the nineteenth century aimed not so much at greater stylistic diversification and poetic advancement but at a growing uniformity, which corresponds to the ideal of a uniform class figuration promoted within the working-class movement at the same time. What was lost - instead of achieved - was the experimental, yet often clumsy, multiformity of Vormärz literature and culture; an aesthetic multiformity, which, in turn, corresponded to the heterogeneous Vormärz class figuration of a "proletarian multiverse" (Karl Heinz Roth). Perhaps the Vormärz was not just a "pre-history" of our modernity - as Sinjen insinuates in her chapter on Weerth - but also one of modernity's great "opportunities not taken". It would be a task of its own to demonstrate how literature not only reflected the process of the uniformness and homogenization of the working class, but also played an active, performative part in this process.

These critical annotations are not meant to diminish the achievements of Beke Sinjen's study; they are, instead, inspired by it. Her study breaks new ground in our understanding of nineteenth-century literature in its relation to social history - a relation that has far too long been obscured by an uncritical notion of "realism". By differentiating this notion and by introducing the category of "social realism”, Sinjen's study encourages social and literary historians alike to consider again the role literature can and does play in the constitution of social reality as a whole.

\section{Patrick Eiden-Offe}

Fakultät für Geisteswissenschaften, Universität Duisburg-Essen Berliner Platz 6-8, Weststadttürme WST-C.07.I 4a, 45 I 27 Essen, Germany E-mail: patrick.eiden-offe@uni-due.de doi: $10.1017 /$ So020859016000298 